\title{
Kinetics and Mechanism of Dimethyl Ether Oxidation to Formaldehyde on Supported Molybdenum Oxide Domains
}

\author{
Patricia Cheung, Haichao Liu, and Enrique Iglesia* \\ Department of Chemical Engineering, University of California at Berkeley, Berkeley, California 94720
}

Received: May 25, 2004; In Final Form: August 17, 2004

\begin{abstract}
Kinetic isotope effect and isotopic tracer/exchange methods were combined with in situ infrared spectroscopy and kinetic data to determine the mechanism of dimethyl ether $\left(\mathrm{DME}, \mathrm{CH}_{3} \mathrm{OCH}_{3}\right)$ oxidation to formaldehyde $(\mathrm{HCHO})$ on $\mathrm{MoO}_{x} / \mathrm{Al}_{2} \mathrm{O}_{3}$. The reaction intermediates and elementary steps established a redox mechanism that led to kinetic rate equations that are consistent with observed dependencies of reactant pressures. Methoxide concentrations as detected by in situ infrared spectroscopy correlated directly with formation rates to establish their importance for the formation of $\mathrm{HCHO}$ and $\mathrm{CH}_{3} \mathrm{OH}$. Reactant partial pressure studies showed that rates of $\mathrm{HCHO}$ and $\mathrm{CH}_{3} \mathrm{OH}$ formation are first-order in DME and zero-order in $\mathrm{O}_{2}$ at low DME pressures. At high DME pressures, rates became independent of DME pressure and acquired positive-order $\mathrm{O}_{2}$ dependencies. $\mathrm{H}-\mathrm{D}$ kinetic isotope effects indicated that $\mathrm{C}-\mathrm{H}$ bond activation is not involved in kinetically relevant steps and transient studies involving $\mathrm{CH}_{3}{ }^{16} \mathrm{OCH}_{3}-{ }^{18} \mathrm{O}_{2}-\mathrm{Mo}^{16} \mathrm{O}_{x} / \mathrm{Al}_{2} \mathrm{O}_{3}$ confirmed the kinetic relevance of DME dissociative adsorption, the step that precedes $\mathrm{C}-\mathrm{H}$ bond activation. These studies also indicated that mechanisms for $\mathrm{HCHO}$ formation do not discriminate between methoxide species formed from DME oxygen and those formed from lattice oxygen. Transient studies with $\mathrm{CH}_{3}{ }^{16} \mathrm{OCH}_{3}-{ }^{16} \mathrm{O}_{2}-{ }^{18} \mathrm{O}_{2}-\mathrm{Mo}^{16} \mathrm{O}_{x} / \mathrm{Al}_{2} \mathrm{O}_{3} \mathrm{did}$ not lead to detectable ${ }^{16} \mathrm{O}-{ }^{18} \mathrm{O}$ levels, indicating that vacancy reoxidation is irreversible.
\end{abstract}

\section{Introduction}

Kinetic and thermodynamic hurdles render current processes for direct methane conversion routes to alkenes and oxygenates too costly for practical implementation. Oxygenates, such as formaldehyde (HCHO), methyl formate (MF), and acetic acid are currently produced via indirect routes involving synthesis gas and methanol as intermediates. Recent advances in shapeselective acid-catalyzed methanol conversion to light alkenes are likely to expand the use of methanol as an intermediate in ethene and propene synthesis processes. ${ }^{1-5}$ Dimethyl ether $\left(\mathrm{DME}, \mathrm{CH}_{3} \mathrm{OCH}_{3}\right)$ is an attractive alternate feedstock in each of these processes because its synthesis provides economic and thermodynamic advantages over $\mathrm{CH}_{3} \mathrm{OH}$ synthesis. 6,7

$\mathrm{MoO}_{x}$ and $\mathrm{VO}_{x}$ domains dispersed on $\mathrm{ZrO}_{2}, \mathrm{SnO}_{2}$, and $\mathrm{Al}_{2} \mathrm{O}_{3}$ supports, and on $\mathrm{Al}_{2} \mathrm{O}_{3}$ surfaces modified by monolayers of $\mathrm{SnO}_{2}, \mathrm{CeO}_{2}$, or $\mathrm{Fe}_{2} \mathrm{O}_{3}$, catalyze DME oxidation to $\mathrm{HCHO}$ with high reaction rates and primary $\mathrm{HCHO}$ selectivities (80-98\%, $\mathrm{CH}_{3} \mathrm{OH}$-free basis $)^{8-11}$ at temperatures $(\sim 500 \mathrm{~K})$ much lower than previously reported. ${ }^{12-14}$ These recent studies have shown that DME oxidation proceeds via parallel and sequential pathways (Scheme 1), which include primary steps leading to $\mathrm{HCHO}, \mathrm{CH}_{3} \mathrm{OH}, \mathrm{MF}$, and $\mathrm{CO}_{x}$ and secondary reactions of $\mathrm{HCHO}$ to form both $\mathrm{MF}$ and $\mathrm{CO}_{x} \cdot{ }^{9}, 10$ The structure and size of active $\mathrm{MoO}_{x}$ domains and the chemical identity of the support used to disperse these domains influence catalytic rates, because the ability of active oxide structures to delocalize charge, a process required to stabilize activated complexes involved in kinetically relevant elementary steps for many oxidation reac-

* To whom correspondence should be addressed. E-mail: iglesia@ cchem.berkeley.edu. Telephone: (510) 642-9673. Fax: (510) 642-4778.
SCHEME 1: Primary and Secondary Pathways in DME Oxidation

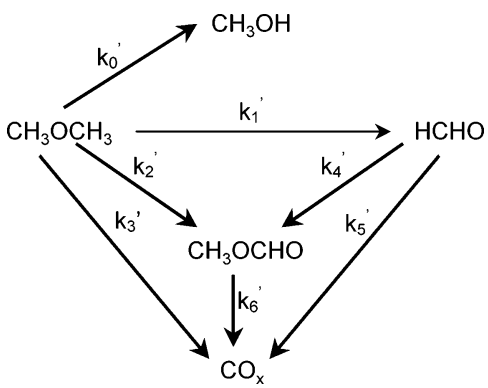

tions, ${ }^{9,10}$ depends on domain size and on the identity of the support. The Lewis acidity of cations in active oxides and support surfaces control the binding and desorption rates of $\mathrm{HCHO}$ and the stability of adsorbed dioxymethylene and formate intermediates involved in $\mathrm{MF}$ and $\mathrm{CO}_{x}$ formation. ${ }^{9}$

Here, we report the results of a mechanistic study of DME oxidation to $\mathrm{HCHO}$ on $\mathrm{MoO}_{3}$ domains. The results indicate that the reaction occurs via redox cycles involving intermediates and elementary steps consistent with the observed kinetic influence of $\mathrm{DME}$ and $\mathrm{O}_{2}$ pressures on oxidation rates and with independent spectroscopic and isotopic data. A highly selective $\mathrm{MoO}_{x} / \mathrm{Al}_{2} \mathrm{O}_{3}$ catalyst, containing about one theoretical polymolybdate monolayer $\left(7 \mathrm{Mo} / \mathrm{nm}^{2}, 15.6\right.$ wt $\left.\% \mathrm{MoO}_{3} / \mathrm{Al}_{2} \mathrm{O}_{3}\right)$, was chosen in an effort to focus the study on $\mathrm{HCHO}$ synthesis pathways with minimal contributions from secondary oxidation reactions. Primary $\mathrm{HCHO}$ selectivities increased with increasing $\mathrm{MoO}_{x}$ loadings on $\mathrm{Al}_{2} \mathrm{O}_{3}$ and reached maximum values ( 98\%) 
at these Mo surface densities $\left(\sim 7 \mathrm{Mo} / \mathrm{nm}^{2}\right) .{ }^{9}$ The polymolybdate structures prevalent at these surface densities also led to nearly complete coverage of $\mathrm{Al}_{2} \mathrm{O}_{3}$ surfaces, thus minimizing acidcatalyzed hydration reactions of DME to form $\mathrm{CH}_{3} \mathrm{OH}$.

\section{Experimental Methods}

2.1. Catalyst Synthesis and Characterization. $\mathrm{MoO}_{x} / \mathrm{Al}_{2} \mathrm{O}_{3}$ catalysts were prepared by incipient wetness impregnation of $\gamma-\mathrm{Al}_{2} \mathrm{O}_{3}$ (Degussa AG, $100 \mathrm{~m}^{2} / \mathrm{g}$ ) with a solution of ammonium heptamolybdate (99\% Aldrich). ${ }^{15}$ The samples were dried overnight in ambient air at $393 \mathrm{~K}$ and treated in dry air (Airgas, zero grade) at $773 \mathrm{~K}$ for $3 \mathrm{~h}$. Mo surface densities are reported as $\mathrm{Mo} / \mathrm{nm}^{2}$, based on the nominal Mo content and the BET surface area after thermal treatment. Surface areas were measured using a five-point BET method and $\mathrm{N}_{2}$ physisorption at its normal boiling point using an Autosorb-1 unit (Quantachrome Corp).

2.2. In Situ Infrared Spectroscopy. Infrared spectra were collected in transmission mode with $2 \mathrm{~cm}^{-1}$ resolution using a Mattson Research Series 1000 spectrometer. Samples (15 mg) were pressed into thin self-supporting wafers and placed within a flow cell with $\mathrm{CaF}_{2}$ windows and a short optical path. Samples were treated within this cell using $0.67 \mathrm{~cm}^{3} / \mathrm{s}$ dry air (Airgas, zero grade) at $773 \mathrm{~K}$ for $1 \mathrm{~h}$ and then cooled to $513 \mathrm{~K}$ before exposure to reactants. Reactants consisted of dimethyl ether (99.5\%, Praxair), dioxygen $\left(90 \% \mathrm{O}_{2} /\right.$ balance $\mathrm{N}_{2}$, Praxair certified mixture), and $\mathrm{He}(99.999 \%$, Airgas), used as an inert component to achieve desired total pressures $(100 \mathrm{kPa})$ and flow rates $(0.67$ $\left.\mathrm{cm}^{3} / \mathrm{s}\right)$. Infrared spectra were collected after contact with reactants for $1 \mathrm{~h}$. Infrared band intensities for gas-phase DME molecules were subtracted from each spectrum to obtain intensities for adsorbed species as a function of the contacting DME partial pressure.

2.3. Steady-State Catalytic Dimethyl Ether Oxidation Reactions on $\mathrm{MoO}_{x} / \mathrm{Al}_{2} \mathrm{O}_{3}$. Steady-state rates and selectivities were measured in a packed-bed flow reactor with plug-flow hydrodynamics. Samples $(0.1-0.3 \mathrm{~g}, 125-250 \mu \mathrm{m})$ were diluted with quartz particles $(0.5-1 \mathrm{~g}, 125-250 \mu \mathrm{m})$ to prevent temperature gradients and to avoid bypassing. The reactor consisted of a stainless steel tube $(7.8 \mathrm{~mm}$ inner diameter $)$ equipped with a multipoint thermocouple held within a $3.4 \mathrm{~mm}$ thermowell aligned along the tube center. Electronic mass flow controllers (Porter Instruments) were used to meter individual reactant streams.

Samples were treated in $0.1 \mathrm{~cm}^{3} / \mathrm{s} 90 \% \mathrm{O}_{2} / 10 \% \mathrm{~N}_{2}$ (Praxair certified mixture) diluted with $0.4 \mathrm{~cm}^{3} / \mathrm{s} \mathrm{He}$ (Airgas, UHP) at $773 \mathrm{~K}$ for $1 \mathrm{~h}$ and then cooled to $513 \mathrm{~K}$ before catalytic measurements. The kinetic effects of DME and $\mathrm{O}_{2}$ pressures were measured at $513 \mathrm{~K}$ and $100-270 \mathrm{kPa}$ total pressures over a wide range of space velocity and $\mathrm{DME}$ and $\mathrm{O}_{2}$ concentrations. Reactant mixtures contained DME (99.5\%, Praxair), dioxygen ( $90 \% \mathrm{O}_{2} /$ balance $\mathrm{N}_{2}$, Praxair certified mixture), and $\mathrm{He}(99.999 \%$, Airgas) as balance. Heat-traced lines (393-423 K) were used to transfer the effluent to an Agilent 6890 gas chromatograph equipped with a methyl silicone capillary column (HP-1, $50 \mathrm{~m}$ $\times 0.32 \mathrm{~mm} \times 1.05 \mu \mathrm{m}$ ) connected to a flame ionization detector (FID) and a Porapak Q packed column (80-100 mesh, $12 \mathrm{ft}$. $\times 1 / 8$ in.) connected to a thermal conductivity detector (TCD). $\mathrm{CH}_{3} \mathrm{OCH}_{3}$ (Matheson, 99.5\%) and $\mathrm{CD}_{3} \mathrm{OCD}_{3}$ (Aldrich, 98 atom $\%$ D) were reacted separately with oxygen $\left(90 \% \quad \mathrm{O}_{2} /\right.$ balance $\mathrm{N}_{2}$, Praxair certified mixture), and He (UHP, Airgas) as balance, to measure $\mathrm{H}-\mathrm{D}$ kinetic isotope effects for DME conversion reactions. An empty reactor did not form detectable amounts of products at temperatures below $590 \mathrm{~K}$.

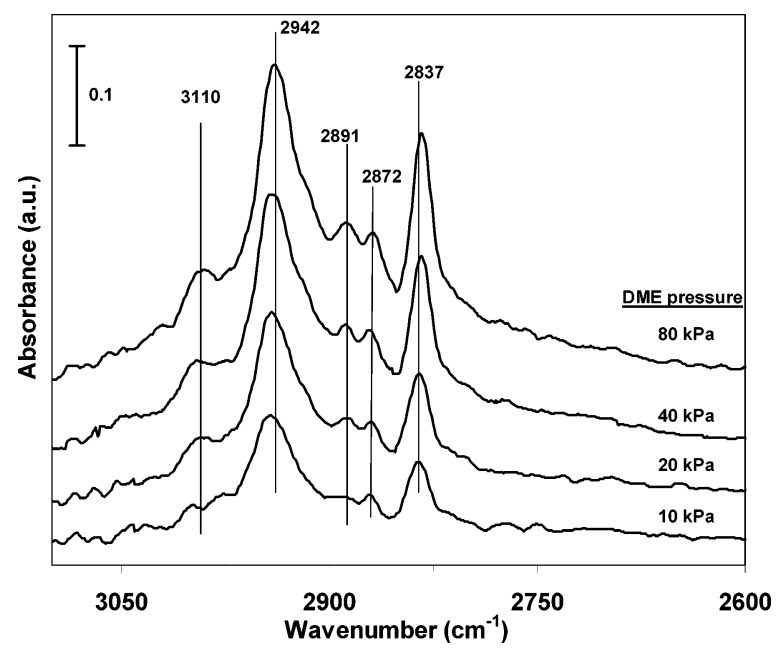

Figure 1. In situ infrared spectra at various DME pressures on 15.6 wt $\% \mathrm{MoO}_{3} / \mathrm{Al}_{2} \mathrm{O}_{3}\left(7 \mathrm{Mo} / \mathrm{nm}^{2}\right)[18 \mathrm{kPa} \mathrm{O}$, balance $\mathrm{He}, 513 \mathrm{~K}]$.

2.4. Isotopic Exchange and Tracer Experiments. A gradientless recirculating batch reactor made of glass was used for isotopic tracer and exchange studies. This approach leads to product evolution profiles with contact time that rigorously reflect those in flow reactors with varying residence time. ${ }^{16}$ The entire system was enclosed in $\mathrm{Al}$ foil and heated to $\sim 323 \mathrm{~K}$ using an ambient air heater to inhibit $\mathrm{HCHO}$ oligomerization and condensation. Reactants and products were circulated over catalyst samples $(0.01-0.03 \mathrm{~g})$ at $3.33 \mathrm{~cm}^{3} / \mathrm{s}$ using a graphite gear micropump. Chemical and isotopic compositions of reactants and products were measured periodically by syringe injection of $1 \mathrm{~cm}^{3}$ gas samples into a gas chromatograph (Agilent 6890) equipped with a mass selective detector (Agilent 5973). Ion yields were analyzed using deconvolution methods that account for natural ${ }^{13} \mathrm{C}$ abundance and for fragmentation patterns to obtain isotopomer distributions for each reactant and product. ${ }^{17}$ Rates and selectivities were simultaneously measured by injection of $1 \mathrm{~cm}^{3}$ samples into the Agilent 6890 gas chromatograph used for flow reactor measurements.

Catalyst samples were treated in $5 \% \mathrm{O}_{2} / 3 \% \mathrm{Ar} / \mathrm{He}$ ( $\mathrm{Scott}$ Specialty Gases, certified master class) at $773 \mathrm{~K}$ for $1 \mathrm{~h}$ before reaction. $\mathrm{CH}_{3}{ }^{16} \mathrm{OCH}_{3}, 5 \%{ }^{16} \mathrm{O}_{2} / 3 \% \mathrm{Ar} / \mathrm{He}, 5 \%{ }^{18} \mathrm{O}_{2} / 2 \% \mathrm{Ar} / \mathrm{He}$ (Isotec, 99 atom $\%{ }^{18} \mathrm{O}$ ) and $\mathrm{He}$ (UHP, Airgas; balance to give $110 \mathrm{kPa}$ total pressure) were used as reactants in isotopic experiments. Isotopic and chemical compositions were measured at $513 \mathrm{~K}$ on $\mathrm{Mo}^{16} \mathrm{O}_{x} / \mathrm{Al}_{2} \mathrm{O}_{3}$ to probe the reversibility of dissociative $\mathrm{O}_{2}$ chemisorption steps. $\mathrm{CH}_{3}{ }^{16} \mathrm{OCH}_{3},{ }^{18} \mathrm{O}_{2}$ (Isotec, 99 atom $\%{ }^{18} \mathrm{O}$ ), and $\mathrm{He}$ (UHP, Airgas) as balance were reacted on $\mathrm{Mo}^{16} \mathrm{O}_{x} / \mathrm{Al}_{2} \mathrm{O}_{3}$ at $488 \mathrm{~K}$ to probe the involvement of lattice oxygen atoms in redox cycles and the reversibility of DME dissociation steps.

\section{Results and Discussion}

3.1. In Situ Infrared Spectroscopy Evidence for Adsorbed Methoxide Intermediates. Figure 1 shows infrared spectra in the $\mathrm{C}-\mathrm{H}$ stretching region during steady-state DME oxidation at $10-80 \mathrm{kPa}$ DME and $513 \mathrm{~K}$. Weak infrared bands at 2891 and $2872 \mathrm{~cm}^{-1}$ are assigned to $\mathrm{C}-\mathrm{H}$ stretches in physisorbed DME; stronger absorption bands at 3110, 2942, and $2837 \mathrm{~cm}^{-1}$ arise from $\mathrm{C}-\mathrm{H}$ stretches in adsorbed methoxide species. These infrared bands were assigned by reference to previous methanol adsorption studies on $\mathrm{MoO}_{3}$ and $\mathrm{V}_{2} \mathrm{O}_{5}{ }^{18-23}$ Briand et al., ${ }^{18}$ Burcham et al., ${ }^{19}$ and Seman et al. ${ }^{24}$ found that methoxide 


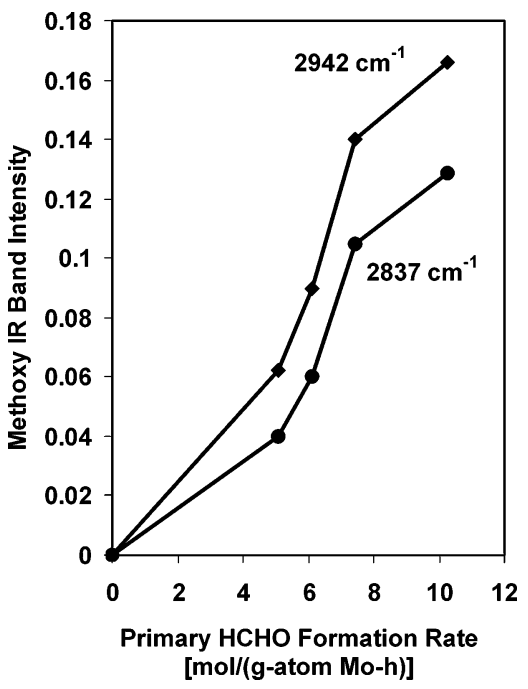

Figure 2. HCHO formation rates plotted vs methoxy FTIR band intensity during DME oxidation on 15.6 wt $\% \mathrm{MoO}_{3} / \mathrm{Al}_{2} \mathrm{O}_{3}(7 \mathrm{Mo} /$ $\mathrm{nm}^{2}$ ) $\left[18 \mathrm{kPa} \mathrm{O}_{2}\right.$, balance $\left.\mathrm{He}, 513 \mathrm{~K}\right]$.

species are present on oxide surfaces during adsorption of $\mathrm{CH}_{3-}$ $\mathrm{OH}$ above $373 \mathrm{~K}$, and that physisorbed methanol coexists with methoxide species at lower temperatures. DME molecules hydrogen-bonded to silanol and acidic $\mathrm{OH}$ groups on HZSM-5 dissociate to form methoxide species identical to those formed from $\mathrm{CH}_{3} \mathrm{OH}$ above $473 \mathrm{~K} .{ }^{20}$

The intensity of these methoxide bands increased with increasing DME pressure (Figure 1) during catalytic oxidation reactions. Thus, active sites are not yet covered with adsorbed methoxide species at these DME concentrations. These studies indicate that physisorption and dissociation of $\mathrm{O}-\mathrm{H}$ bonds in $\mathrm{CH}_{3} \mathrm{OH}$ and of $\mathrm{C}-\mathrm{O}$ bonds in DME to form methoxide species occur at typical catalytic oxidation temperatures. Only very weak signals were detected in the $\mathrm{C}=\mathrm{O}$ and $\mathrm{O}-\mathrm{H}$ regions, indicating that the observed $\mathrm{C}-\mathrm{H}$ stretches did not arise from molecularly adsorbed $\mathrm{HCHO}$ or $\mathrm{CH}_{3} \mathrm{OH}$.

Methoxide species and physisorbed DME exist on the catalyst surface during DME oxidation and methoxide groups appear to be the reactive intermediates in $\mathrm{HCHO}$ synthesis from DME. This intermediate role of methoxide species is consistent with the data shown in Figure 2, which show that DME conversion rates and the intensities of the methoxide bands at 2837 and $2942 \mathrm{~cm}^{-1}$ in Figure 1 increase in parallel with increasing DME pressures $(10-80 \mathrm{kPa})$. These data suggest the direct involvement of methoxide species in DME oxidation.

3.2. Effects of Reactant Concentrations on Primary $\mathrm{HCHO}$ and $\mathrm{CH}_{3} \mathrm{OH}$ Formation Rates. Figure 3 shows the effects of DME partial pressure on primary $\mathrm{HCHO}$ and $\mathrm{CH}_{3-}$ $\mathrm{OH}$ formation rates at $513 \mathrm{~K}$ and $100-270 \mathrm{kPa}$ total pressures. Primary rates were obtained by extrapolating measured rates to zero reactant residence time for each reactant concentration. $\mathrm{HCHO}$ and $\mathrm{CH}_{3} \mathrm{OH}$ rates increased with DME pressure at low pressures and then approached nearly constant values above 150 $\mathrm{kPa}$, as active surfaces became populated with methoxide and methoxide-derived species (hydroxyl groups, vacancies).

The ratio of $\mathrm{HCHO}$ to $\mathrm{CH}_{3} \mathrm{OH}$ formation rates decreased with increasing DME pressure and approached a value of unity, consistent with the stoichiometry for

$$
\mathrm{CH}_{3} \mathrm{OCH}_{3}+{ }^{1 / 2} \mathrm{O}_{2} \rightarrow \mathrm{CH}_{3} \mathrm{OH}+\mathrm{HCHO}
$$

a reaction in which lattice oxygens are used stoichiometrically (and ultimately vacancies are replenished by $\mathrm{O}_{2}$ ) to form $\mathrm{CH}_{3-}$

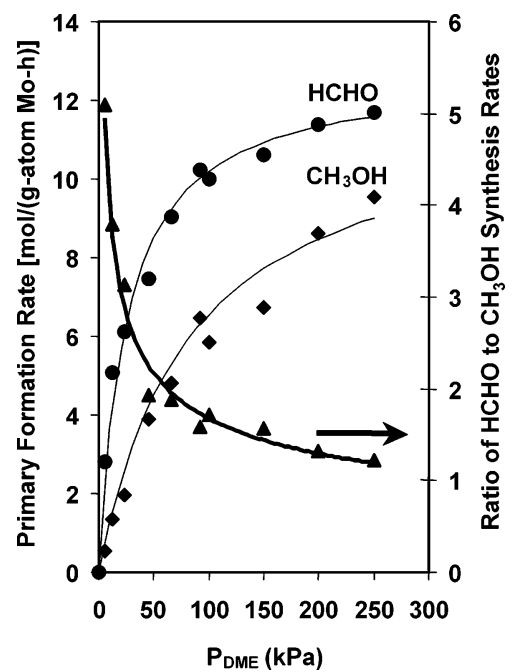

Figure 3. Effect of DME concentration on formaldehyde and methanol synthesis rates on 15.6 wt $\% \mathrm{MoO}_{3} / \mathrm{Al}_{2} \mathrm{O}_{3}\left(7 \mathrm{Mo} / \mathrm{nm}^{2}\right)[18 \mathrm{kPa} \mathrm{O}$, balance $\mathrm{He}, 513 \mathrm{~K}]$.

$\mathrm{OH}$, instead of $\mathrm{H}_{2} \mathrm{O}$, which typically forms in methanol oxidation reactions via $\mathrm{OH}$ recombination. $\mathrm{CH}_{3} \mathrm{OH}$ is likely to form by reactions of $\mathrm{OH}$ groups, formed during $\mathrm{H}$-abstraction from methoxide species, with other methoxides, in a step also required for DME hydration to $\mathrm{CH}_{3} \mathrm{OH}$, which occurs concurrently during DME oxidation as $\mathrm{H}_{2} \mathrm{O}$ product concentration increases with increasing residence time. This equimolar formation of $\mathrm{CH}_{3} \mathrm{OH}$ and $\mathrm{HCHO}$ becomes less likely as methoxide concentrations decrease and $\mathrm{OH}$ groups react with each other instead to form $\mathrm{H}_{2} \mathrm{O}$, to give the stoichiometry for oxidative dehydrogenation:

$$
\mathrm{CH}_{3} \mathrm{OCH}_{3}+\mathrm{O}_{2} \rightarrow 2 \mathrm{HCHO}+\mathrm{H}_{2} \mathrm{O}
$$

At low DME pressures and low adsorbed methoxide concentrations, routes to $\mathrm{HCHO}$ are favored over those leading to $\mathrm{CH}_{3}-$ $\mathrm{OH}$ because hydroxyl groups tend to recombine and desorb as $\mathrm{H}_{2} \mathrm{O}$ before reacting with adsorbed methoxide species. ${ }^{25}$ As active sites become populated with adsorbed methoxide, $\mathrm{OH}$ recombination occurs less frequently, and $\mathrm{CH}_{3} \mathrm{OH}$ formation becomes the dominant hydroxyl-rejection pathway. Indeed, the ratio of $\mathrm{HCHO}$ to $\mathrm{CH}_{3} \mathrm{OH}$ in products decreased to values near unity as DME pressure increased and $\mathrm{OH}$ groups are removed only via reactions with methoxide. This stoichiometry indicates that HCHO essentially free of water can be formed, at least at low conversion, via the oxidation of DME at high pressures. This result, together with the fact that the stoichiometry for DME oxidation leads to half the amount of water formed in $\mathrm{CH}_{3} \mathrm{OH}$ oxidation processes in commercial practice, may lead to higher $\mathrm{HCHO}$ purities and lower water removal costs.

The effects of $\mathrm{O}_{2}$ partial pressure $(5-75 \mathrm{kPa})$ on $\mathrm{HCHO}$ formation rates are shown in Figure 4 at two DME pressures $(20$ and $150 \mathrm{kPa})$. At $20 \mathrm{kPa}$ DME, HCHO formation rates are nearly zero-order in $\mathrm{O}_{2}$ pressure and increase linearly with DME pressure (Figures 3 and 4). In contrast, at DME pressures giving near zero-order DME effects on reaction rates $(150 \mathrm{kPa}), \mathrm{HCHO}$ formation rates acquire a positive-order dependence on $\mathrm{O}_{2}$ concentration and then become nearly independent of $\mathrm{O}_{2}$ at higher $\mathrm{O}_{2}$ partial pressures. These kinetic responses are reminiscent of catalytic reactions involving Mars-van Krevelen ${ }^{26}$ redox cycles on reducible oxides with labile lattice oxygens, such as those involved in $\mathrm{CH}_{3} \mathrm{OH}$ oxidation to $\mathrm{HCHO}^{27}$ and oxidative dehydrogenation of alkanes. ${ }^{28-30}$ Thus, we suggest below a similar type of redox mechanism for DME oxidation 


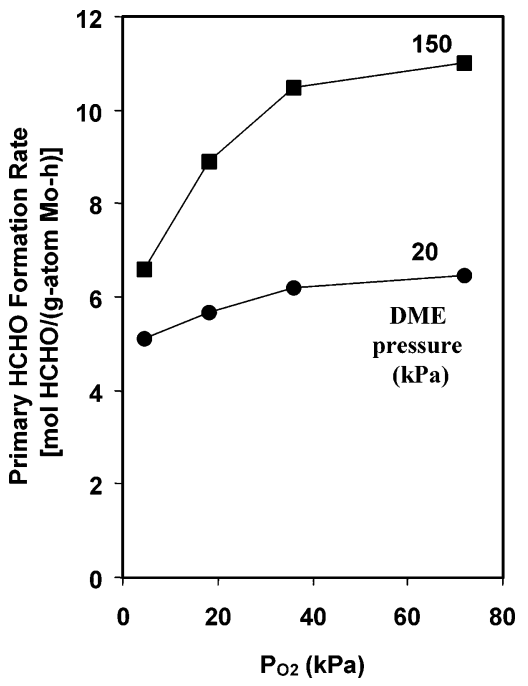

Figure 4. Effect of $\mathrm{O}_{2}$ concentration on formaldehyde synthesis rates on 15.6 wt $\% \mathrm{MoO}_{3} / \mathrm{Al}_{2} \mathrm{O}_{3}\left(7 \mathrm{Mo} / \mathrm{nm}^{2}\right)$ [balance $\mathrm{He}, 513 \mathrm{~K}$ ].

SCHEME 2: Reactive Intermediates

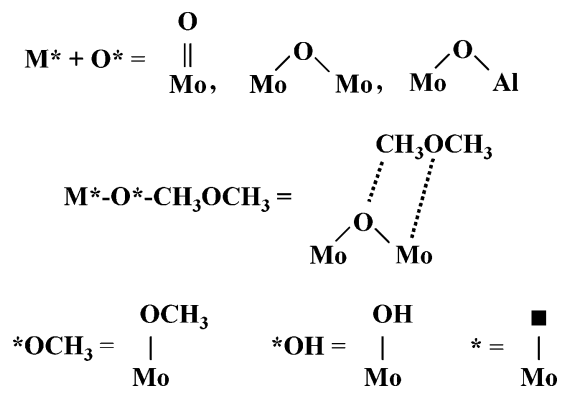

and provide isotopic evidence for the kinetic relevance and reversibility of specific steps and for the role of lattice oxygen atoms in DME oxidation.

The scheme below shows a plausible sequence of elementary steps, although as in most mechanistic proposals, not the only possible one. In this scheme, $\mathrm{O}^{*}$ and $\mathrm{M}^{*}$ represent a lattice oxygen and a metal center connected to a lattice oxygen $\left(\mathrm{Mo}_{-}\right.$ $\mathrm{O}$, or $\mathrm{Mo}=\mathrm{O})$, respectively. $* \mathrm{OCH}_{3}$ corresponds to methoxide intermediates and $* \mathrm{OH}$ and * represent hydroxyl groups and lattice oxygen vacancies, respectively. We note that the kinetic analysis described below is identical whether the bridging $\mathrm{M}-\mathrm{O}-\mathrm{M}$ or terminal $\mathrm{M}=\mathrm{O}$ bonds are involved in $\mathrm{C}-\mathrm{O}$ or $\mathrm{C}-\mathrm{H}$ activation. Thus, a kinetic treatment by itself cannot provide information about the specific sites involved in elementary steps. Schematic depictions of the reactive intermediates are shown in Scheme 2.

1. Quasi-equilibrated nondissociative DME chemisorption.

$$
\mathrm{CH}_{3} \mathrm{OCH}_{3}+\mathrm{M}^{*}+\mathrm{O}^{*} \stackrel{K_{1}}{\Leftrightarrow} \mathrm{M}^{*}-\mathrm{O}^{*}-\mathrm{CH}_{3} \mathrm{OCH}_{3}
$$

2. Irreversible DME dissociation via concerted interactions with lattice oxygen and metal center to form two $\mathrm{OCH}_{3}$ intermediates.

$$
\mathrm{M} *-\mathrm{O} *-\mathrm{CH}_{3} \mathrm{OCH}_{3} \stackrel{k_{2}}{\longrightarrow} * \mathrm{OCH}_{3}+* \mathrm{OCH}_{3}
$$

3. Irreversible hydrogen abstraction from $* \mathrm{OCH}_{3}$ using neighboring oxygen atom to form $\mathrm{HCHO}, * \mathrm{OH}$, and a reduced Mo cation.

$$
* \mathrm{OCH}_{3}+\mathrm{O} * \stackrel{k_{3}}{\rightarrow} *+* \mathrm{OH}+\mathrm{HCHO}
$$

4. Reversible reaction of $* \mathrm{OCH}_{3}$ and $* \mathrm{OH}$ groups to form methanol.

$$
* \mathrm{OCH}_{3}+* \mathrm{OH} \underset{k_{-4}}{\stackrel{k_{4}}{\rightleftarrows}} \mathrm{M}^{*}+\mathrm{O}^{*}+\mathrm{CH}_{3} \mathrm{OH}
$$

5. Reversible reaction of two $* \mathrm{OH}$ groups to form water.

$$
* \mathrm{OH}+* \mathrm{OH} \underset{k_{-5}}{\stackrel{k_{5}}{\leftrightarrows}} \mathrm{M}^{*}+\mathrm{O}^{*}+\mathrm{H}_{2} \mathrm{O}
$$

6. Irreversible reoxidation of reduced Mo centers via dissociative chemisorption of $\mathrm{O}_{2}$.

$$
*+*+\mathrm{O}_{2} \stackrel{k_{6}}{\rightarrow} \mathrm{O} *+\mathrm{O} *
$$

Methoxide groups can either react with lattice oxygen to form $\mathrm{HCHO}$ or they can react with surface hydroxyl groups formed during $\mathrm{C}-\mathrm{H}$ bond activation steps to form methanol. The overall reaction stoichiometry is

$$
\begin{array}{r}
\mathrm{CH}_{3} \mathrm{OCH}_{3}+\left(1-\frac{\alpha}{2}\right) \mathrm{O}_{2} \rightarrow(2-\alpha) \mathrm{HCHO}+\alpha \mathrm{CH}_{3} \mathrm{OH}+ \\
(1-\alpha) \mathrm{H}_{2} \mathrm{O}
\end{array}
$$

where

$$
\begin{gathered}
\alpha=\frac{r_{\mathrm{CH}_{3} \mathrm{OH}}}{r_{\mathrm{HCHO}}}=\frac{\mathrm{k}_{4}[* \mathrm{OH}]}{\mathrm{k}_{3}\left[\mathrm{O}^{*}\right]} \\
0 \leq \alpha \leq 1
\end{gathered}
$$

In our derivation, we assume that equilibrium for the methanol formation step lies to the right $\left(k_{4}\left[* \mathrm{OCH}_{3}\right]\left[\mathrm{OH}^{*}\right] \gg k_{-4}[\mathrm{M} *]\right.$ $\left.[\mathrm{O} *] P_{\mathrm{CH}_{3} \mathrm{OH}}\right)$, because methanol conversion to products at our low DME conversion levels $(0-10 \%)$ was undetected in our space velocity studies. Values of $\alpha$ range between 0 (when $\mathrm{OH}$ recombination leads to $\mathrm{H}_{2} \mathrm{O}$ at low DME pressures) and 1 (for methoxide $-\mathrm{OH}$ recombination to form $\mathrm{CH}_{3} \mathrm{OH}$ at high DME pressures).

Pseudo-steady-state analysis of $\mathrm{M}^{*}, \mathrm{O} *,{ }^{*} \mathrm{OCH}_{3}, * \mathrm{OH}$, and * with the stated quasi-equilibrium assumptions do not give simple analytical closed-form solutions. As a result, we derive instead rate equations for asymptotic cases in which surfaces are essentially uncovered (low DME pressure) and in which the surface becomes populated with intermediates (high DME pressure). The full derivation is given in the Appendix.

At low DME pressures, methanol is not formed (step 4 is negligible). The rate of $\mathrm{HCHO}$ formation becomes

$$
r_{\mathrm{HCHO}}=\frac{1}{4} K_{1} k_{2} P_{\mathrm{DME}}=k_{\mathrm{eff}, 1} P_{\mathrm{DME}}
$$

At high DME pressure, the rates of $\mathrm{HCHO}$ and methanol formation become equal and water is not formed (step 5 is negligible). We will provide experimental evidence in the next section to show that methoxide and hydroxyl surface concentrations are small throughout our kinetic and isotopic studies; they do not become abundant surface intermediates. Additionally, as DME pressures increase relative to $\mathrm{O}_{2}$ pressures, the concentration of oxygen vacancies increases. When oxygen is limited, lattice oxygen vacancies become abundant and the rate of $\mathrm{HCHO}$ synthesis approaches

$$
r_{\mathrm{HCHO}}=\frac{1}{2} k_{6} P_{\mathrm{O}_{2}}=k_{\mathrm{eff}, 2} P_{\mathrm{O}_{2}}
$$



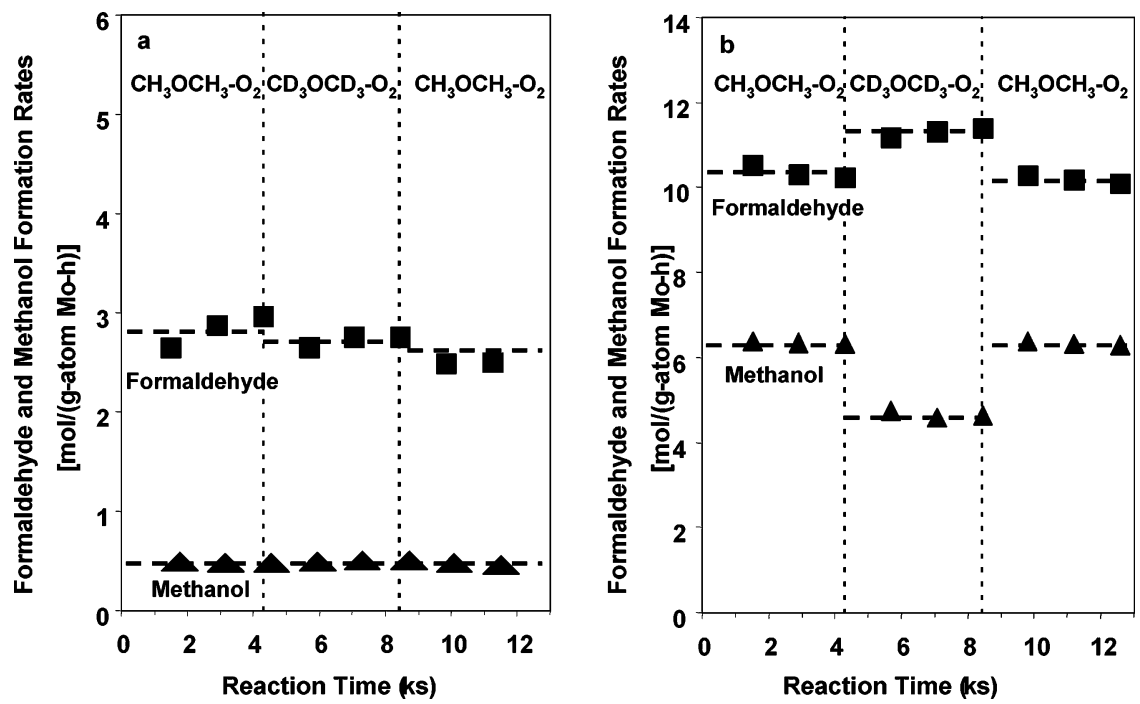

Figure 5. Formaldehyde and methanol kinetic isotope effects at $5 \mathrm{kPa}$ (a) and $150 \mathrm{kPa}$ (b) $\mathrm{DME}\left(18-20 \mathrm{kPa} \mathrm{O}_{2}, 513 \mathrm{~K}\right)$.

TABLE 1: Kinetic Isotope Effects on $15.6 \mathrm{wt} \% \mathrm{MoO}_{3} /$ $\mathrm{Al}_{2} \mathrm{O}_{3}\left(7 \mathrm{Mo} / \mathrm{nm}^{2}\right)$ at $513 \mathrm{~K}$

\begin{tabular}{ccccc}
\hline & & \multicolumn{3}{c}{$\mathrm{KIE}\left(\mathrm{r}_{\mathrm{H}} / \mathrm{r}_{\mathrm{d}}\right)$} \\
\cline { 3 - 5 }$P_{\mathrm{DME}}(\mathrm{kPa})$ & $P_{\mathrm{O}_{2}}(\mathrm{kPa})$ & formaldehyde & methanol & $\mathrm{DME}$ \\
\hline 5.0 & 19.8 & 1.0 & 1.0 & 1.0 \\
53.3 & 24.2 & 1.1 & 1.0 & 1.1 \\
80.0 & 24.2 & 1.1 & 1.2 & 1.1 \\
150.0 & 18.0 & 0.9 & 1.4 & 1.0
\end{tabular}

3.3. $\mathrm{CH}_{3} \mathrm{OCH}_{3}-\mathrm{CD}_{3} \mathrm{OCD}_{3}$ Kinetic Isotope Effects. Kinetic isotope effects were measured from primary formaldehyde and methanol synthesis rates and DME conversion rates with $\mathrm{CH}_{3-}$ $\mathrm{OCH}_{3}-\mathrm{O}_{2}$ and $\mathrm{CD}_{3} \mathrm{OCD}_{3}-\mathrm{O}_{2}$ reactant mixtures at various DME pressures $(5-150 \mathrm{kPa})$ and $513 \mathrm{~K}$. Figure 5 shows formaldehyde and methanol synthesis rates at 5 and $150 \mathrm{kPa}$ DME. The corresponding kinetic isotope effects are shown in Table 1. At $5 \mathrm{kPa}$ DME pressures, no significant kinetic isotope effects were detected for either formaldehyde or methanol synthesis. At $150 \mathrm{kPa}$, a small normal kinetic isotope effect (1.4) was measured for methanol synthesis, while formaldehyde synthesis showed a small inverse kinetic isotope effect (0.9). The formaldehyde and methanol KIE values combine to give overall kinetic isotope effects near unity for total DME conversion rates at all pressures tested. These small kinetic isotope effects are inconsistent with any kinetic relevance of steps involving hydrogen abstraction; they suggest instead that kinetically relevant elementary steps throughout the entire DME pressure range do not require the formation or cleavage of bonds containing hydrogen atoms.

The observed formaldehyde and methanol isotope effects at $150 \mathrm{kPa}$ DME, although not large in comparison to those measured in methanol oxidation (as described below), are worthy of discussion. The mechanism branches under reaction conditions that lead to both formaldehyde and methanol formation. Here, the individual KIE values arise from $\mathrm{H}-\mathrm{D}$ influenced formaldehyde and methanol selectivities. Thus, there may now be an equilibrium isotope effect that reflects the relative stabilities of $\mathrm{OH}$ and OD. Formaldehyde formation is favored if the oxygen lattice readily accepts protons to form hydroxyl groups. Conversely, if hydroxyl groups are relatively unstable, they tend to combine with methoxides to generate methanol. Our results indicate that the latter occurs as larger methanol and smaller formaldehyde formation rates arise when the reactant is switched from protonated to deuterated DME.
In addition, since neither $\mathrm{HCHO}$ nor $\mathrm{CH}_{3} \mathrm{OH}$ isotope effects become substantial, neither methoxide nor hydroxyl groups become the most abundant reactive intermediates over the range of DME and $\mathrm{O}_{2}$ pressures tested. If either intermediate became a significant contributor to the pool of reactive species, the rate constants for $\mathrm{C}-\mathrm{H}$ or $\mathrm{O}-\mathrm{H}$ activation in $\mathrm{HCHO}$ (step 3), $\mathrm{CH}_{3-}$ $\mathrm{OH}$ (step 4), and/or $\mathrm{H}_{2} \mathrm{O}$ (step 5) formation steps would appear in the overall $\mathrm{HCHO}$ formation rate equation and measured rates would exhibit kinetic isotope effects much stronger than those measured.

Previous studies have reported kinetic isotope effects of 3-4 for oxidative dehydrogenation of methanol on $\mathrm{MoO}_{3}$ and iron molybdate catalysts at $473-608 \mathrm{~K}$, as expected from $\mathrm{C}-\mathrm{H}$ bond activation in methoxide species as the kinetically relevant step in HCHO synthesis. ${ }^{31}$ Our scheme for DME oxidation also involves methoxide intermediates, but we conclude based on measured KIE values that kinetically relevant steps in DME oxidation must involve the formation of methoxide intermediates (at low DME pressures) and the reoxidation of vacancy intermediates (at high DME pressures), neither of which involves reactions of chemical bonds containing hydrogen atoms. Thus, we suggest that the first-order rate constant, $k_{\text {eff. }}$, for DME oxidation at low pressures reflects those for DME dissociation steps (step 2) on nearly uncovered surfaces $\left(\mathrm{M}^{*}\right.$ and $\mathrm{O}^{*}$ as most abundant reactive intermediates); this conclusion is confirmed by the isotopic tracer and exchange measurements described below. The positive-order dependence on $\mathrm{O}_{2}$ pressure at high DME pressures indicates that reoxidation of reduced centers becomes kinetically relevant when surface vacancies become the most abundant reactive intermediates; the rate of this step does not depend on whether protium or deuterium are present in dimethyl ether reactants.

The HCHO formation rate equation at low DME pressures indicates that kinetic isotope effects reflect the ratio of rate constants given by

$$
\mathrm{KIE}_{\mathrm{HCHO}}=\frac{k_{\text {eff, }, 1, \mathrm{H}}}{k_{\mathrm{eff}, 1, \mathrm{D}}}=\frac{K_{1, \mathrm{H}} k_{2, \mathrm{H}}}{K_{1, \mathrm{D}} k_{2, \mathrm{D}}}
$$

No H-D kinetic isotope effects are expected for DME physisorption and only weak effects for DME dissociation $\left(K_{1}\right.$ and $k_{2}$ ), because these steps do not involve $\mathrm{C}-\mathrm{H}$ bond cleavage. 
The lack of a detectable kinetic isotope effect rules out any kinetic effects of $\mathrm{C}-\mathrm{H}$ bond activation steps on the overall reaction and confirms the alternate kinetic relevance of DME dissociation at low DME reactant pressures.

Reaction rates at high DME pressures are only weakly influenced by $\mathrm{H}-\mathrm{D}$ substitution and predominately reflect the values of the rate constants for reoxidation of oxygen vacancies:

$$
\mathrm{KIE}_{\mathrm{HCHO}}=\frac{k_{\text {eff }, 2, \mathrm{H}}}{k_{\text {eff }, 2, \mathrm{D}}}=\frac{k_{6, \mathrm{H}}}{k_{6, \mathrm{D}}}
$$

No $\mathrm{H}-\mathrm{D}$ kinetic isotope effects are expected for vacancy reoxidation $\left(k_{6}\right)$ because this step also does not involve $\mathrm{C}-\mathrm{H}$ bond cleavage.

3.4. Isotopic Evidence for the Involvement of Lattice Oxygen Atoms and for the Reversibility of Dimethyl ether Dissociation Steps. Reactions of $\mathrm{CH}_{3} \mathrm{OCH}_{3}-\mathrm{CD}_{3} \mathrm{OCD}_{3}-\mathrm{O}_{2}$ reactant mixtures were initially used to probe the reversibility of DME dissociation (step 2), but mixed DME isotopomers formed on $\mathrm{Al}_{2} \mathrm{O}_{3}$ supports and even on quartz reactor walls via acid-catalyzed DME-methanol interconversions involving water molecules formed in oxidation steps. Thus, these experiments failed to probe the reversibility of catalytically relevant steps that cleave and re-form $\mathrm{C}-\mathrm{O}$ bonds in dimethyl ether.

Instead, we have used reactions of $\mathrm{CH}_{3}{ }^{16} \mathrm{OCH}_{3}-{ }^{18} \mathrm{O}_{2}$ mixtures on $\mathrm{Mo}^{16} \mathrm{O}_{3} / \mathrm{Al}_{2}{ }^{16} \mathrm{O}_{3}$ to probe concurrently the reversibility of DME dissociation steps, as well as the involvement of lattice oxygen atoms in $\mathrm{HCHO}$ formation. Involvement by lattice oxygen atoms would lead to the initial formation of $\mathrm{HCH}^{16} \mathrm{O}$ until lattice ${ }^{16} \mathrm{O}$ atoms become ultimately depleted and replaced by ${ }^{18} \mathrm{O}$ from ${ }^{18} \mathrm{O}_{2}$ co-reactants. Also, the involvement of lattice oxygen atoms would lead to significant ${ }^{18} \mathrm{O}$ introduction into unreacted DME, as lattice ${ }^{16} \mathrm{O}$ is replaced by ${ }^{18} \mathrm{O}$ from ${ }^{18} \mathrm{O}_{2}$, if DME dissociation steps are reversible and quasi-equilibrated.

We address first the involvement of lattice oxygen, because it is required before experimental data can be used to probe the reversibility of DME dissociation steps. Figure 6 shows the total (or cumulative) formation turnovers normalized per Mo for $\mathrm{HCHO}$ and $\mathrm{CH}_{3} \mathrm{OH}$ isotopomers containing either ${ }^{16} \mathrm{O}$ or ${ }^{18} \mathrm{O}$ isotopes and their respective mole fractions as functions of residence time in a recirculating reactor at $488 \mathrm{~K}$. Initially, when few ${ }^{18} \mathrm{O}$ atoms have replaced the ${ }^{16} \mathrm{O}$ initially present in the $\mathrm{MoO}_{3}$ lattice, $\mathrm{HCHO}$ and $\mathrm{CH}_{3} \mathrm{OH}$ contain mostly ${ }^{16} \mathrm{O}$, as expected if lattice oxygens contributed the second $\mathrm{O}$ atom required to form two oxygenates from each $\mathrm{CH}_{3}{ }^{16} \mathrm{OCH}_{3}$ molecule. As lattice oxygen vacancies form during turnovers and become reoxidized by ${ }^{18} \mathrm{O}_{2}$, the ${ }^{18} \mathrm{O}$ content in $\mathrm{HCHO}$ approached the $50 \%$ level expected as DME dissociates to form two indistinguishable methoxide groups containing one lattice oxygen and one oxygen atom from DME. The greater ${ }^{16} \mathrm{O}$ abundance in $\mathrm{CH}_{3} \mathrm{OH}$ relative to $\mathrm{HCHO}$ indicates that $\mathrm{CH}_{3} \mathrm{OH}$ is also formed via hydration of $\mathrm{CH}_{3}{ }^{16} \mathrm{OCH}_{3}$ reactants, possibly on Lewis sites prevalent on the fractional portions of exposed $\mathrm{Al}_{2} \mathrm{O}_{3}$ support surfaces and without direct contribution from lattice oxygen. The $\mathrm{CH}_{3}{ }^{16} \mathrm{OH}$ isotopomer concentration reaches an upper limit of $50 \%$ if methanol arises only from methoxide and hydroxyl groups chemisorbed on the $\mathrm{Mo}^{18} \mathrm{O}_{x}$ lattice. The ending $\mathrm{CH}_{3}{ }^{16} \mathrm{OH}$ isotopomer concentration of $75 \%$ indicates that some methanol must result from reversible acid-catalyzed DME hydration reactions on exposed $\mathrm{Al}_{2} \mathrm{O}_{3}$. This introduces some complexity into our attempt to use these data to determine the reversibility of DME dissociation steps.
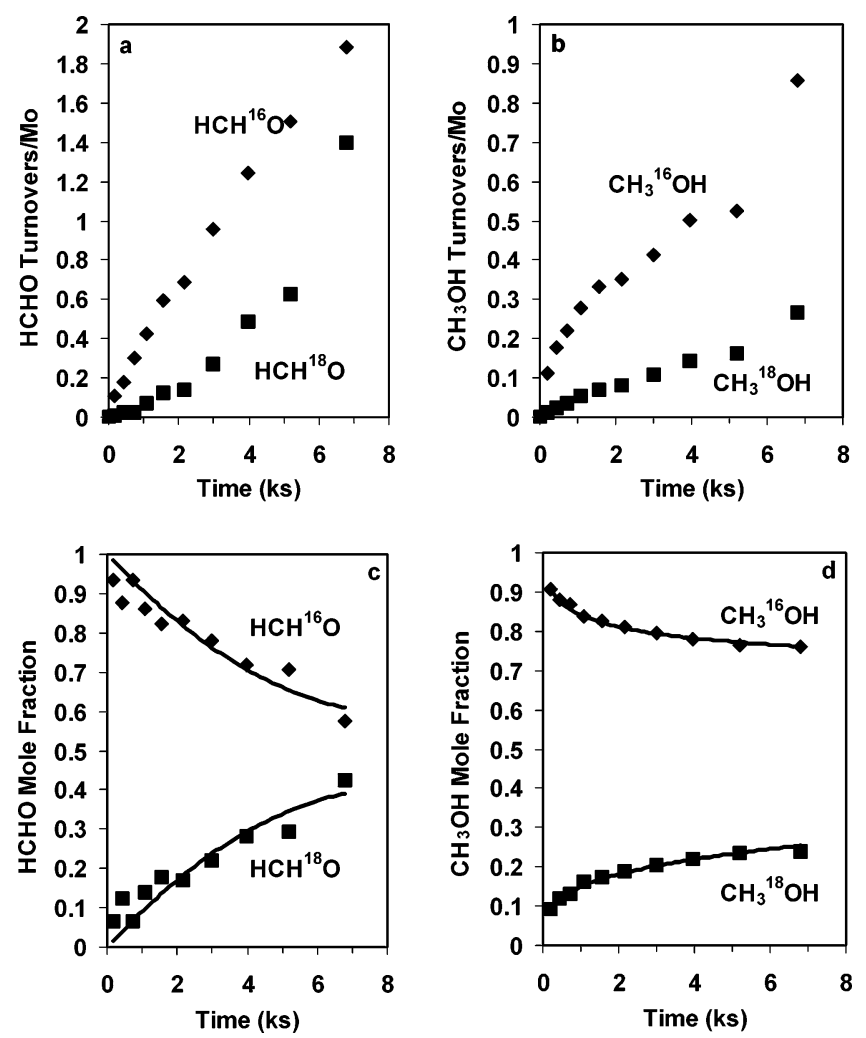

Figure 6. Cumulative (a) formaldehyde and (b) methanol isotopomer turnovers in ${ }^{18} \mathrm{O}_{2}-\mathrm{CH}_{3}{ }^{16} \mathrm{OCH}_{3}$ mixtures on $15.6 \mathrm{wt} \% \mathrm{Mo}^{16} \mathrm{O}_{3} / \mathrm{Al}_{2}{ }^{16} \mathrm{O}_{3}$ $\left(7 \mathrm{Mo} / \mathrm{nm}^{2}\right.$ ) and (c) formaldehyde and (d) methanol isotopomer distributions [13.6 $\mathrm{kPa} \mathrm{CH}_{3}{ }^{16} \mathrm{OCH}_{3}, 20 \mathrm{kPa}{ }^{18} \mathrm{O}_{2}$, balance $\mathrm{He}, 488 \mathrm{~K}$, gradientless batch reactor].
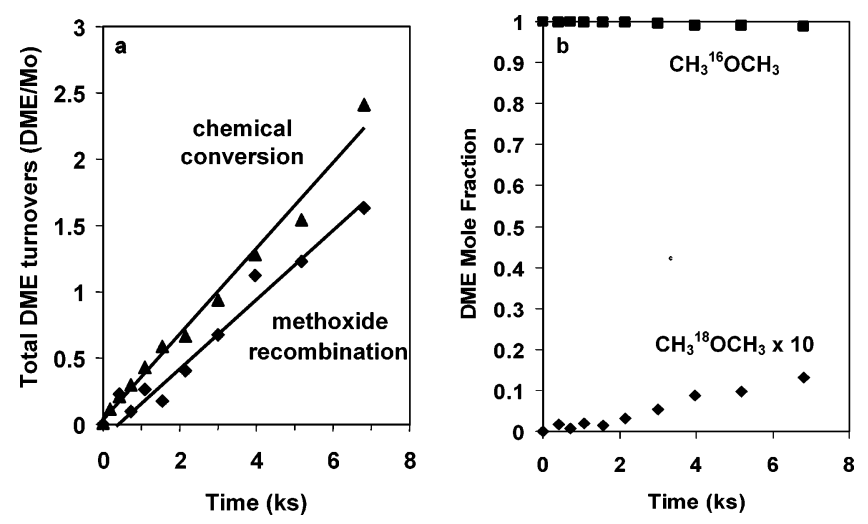

Figure 7. Total turnovers for DME chemical conversion and methoxy combination to re-form DME in ${ }^{18} \mathrm{O}_{2}-\mathrm{CH}_{3}{ }^{16} \mathrm{OCH}_{3}$ (a) and DME isotopomer distribution (b) in mixtures on $15.6 \mathrm{wt} \% \mathrm{Mo}^{16} \mathrm{O}_{3} / \mathrm{Al}_{2} \mathrm{O}_{3}$ (7 $\mathrm{Mo} / \mathrm{nm}^{2}$ ) [13.6 $\mathrm{kPa} \mathrm{CH}_{3}{ }^{16} \mathrm{OCH}_{3}, 20 \mathrm{kPa}{ }^{18} \mathrm{O}_{2}$, balance $\mathrm{He}, 488 \mathrm{~K}$, gradientless batch reactor].

Figure 7 shows total DME chemical conversion turnovers and methoxide recombination turnovers per Mo to form DME in the reverse of step 2 . The latter were estimated as twice the number of $\mathrm{CH}_{3}{ }^{18} \mathrm{OCH}_{3}$ formation turnovers, because after initial stages of the reaction, lattice oxygens are mostly ${ }^{18} \mathrm{O}$ and methoxide groups contain equal numbers of ${ }^{16} \mathrm{O}$ and ${ }^{18} \mathrm{O}$ atoms. The ratio of the rates of DME chemical conversion of reversible DME dissociation by methoxide recombination, as calculated from the slope of the graphs, is $\sim 1.3$, suggesting that DME dissociation may be reversible, but not quasi-equilibrated, during DME oxidation to $\mathrm{HCHO}$ on this catalyst. Quasi-equilibration requires the rate of methoxide recombination to be considerably 


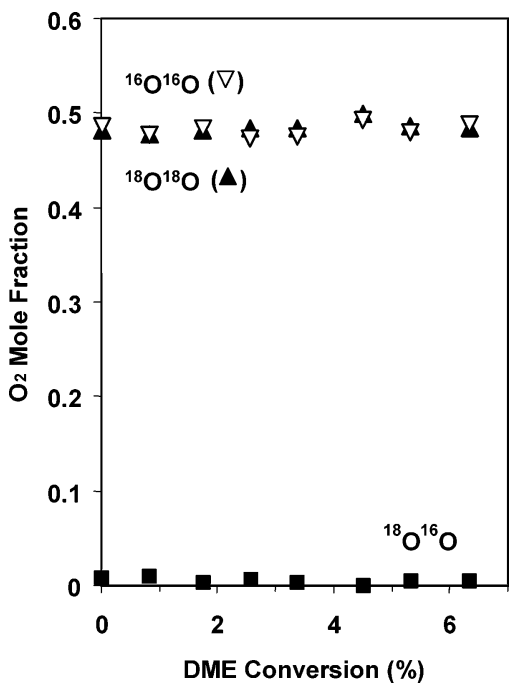

Figure 8. ${ }^{18} \mathrm{O}^{16} \mathrm{O}$ mole fraction in $\mathrm{O}_{2}$ reactant during the reaction of $\mathrm{CH}_{3} \mathrm{OCH}_{3}$ and a mixture of ${ }^{16} \mathrm{O}_{2}-{ }^{18} \mathrm{O}_{2}$ on 15.6 wt $\% \mathrm{MoO}_{3} / \mathrm{Al}_{2} \mathrm{O}_{3}(7$ $\mathrm{Mo} / \mathrm{nm}^{2}$ ) [17 kPa DME, $2.4 \mathrm{kPa}{ }^{16} \mathrm{O}_{2}, 2.4 \mathrm{kPa}{ }^{18} \mathrm{O}_{2}$, balance He, 513 $\mathrm{K}$, gradientless batch reactor].

larger than that of chemical reaction and it would have led to similar ${ }^{18} \mathrm{O}$ contents in DME reactants and in all reaction products. Figure $7 \mathrm{~b}$ shows that this is not the case. This rate of ${ }^{18} \mathrm{O}$ introduction into DME is, in fact, an upper limit for the rate of the reverse of step 2, because the reversible reaction of $\mathrm{CH}_{3}{ }^{16} \mathrm{OCH}_{3}$ with $\mathrm{H}_{2}{ }^{18} \mathrm{O}$ formed during $\mathrm{HCHO}$ synthesis via hydration reactions occurs and leads to ${ }^{18} \mathrm{O}$ introduction into "unreacted" DME. Thus, our assumption that step 2 is essentially irreversible in deriving kinetic rate equations consistent with experimental data appears to be justified.

The irreversible nature of $\mathrm{O}_{2}$ dissociative chemisorption steps on surface vacancies (step 6) was examined by measuring the dioxygen isotopomers formed during reactions of $\mathrm{CH}_{3}{ }^{16} \mathrm{OCH}_{3}$ with equimolar ${ }^{16} \mathrm{O}_{2}-{ }^{18} \mathrm{O}_{2}$ mixtures. Quasi-equilibrium would lead to binomial dioxygen isotopomers $\left(50 \%{ }^{16} \mathrm{O}^{18} \mathrm{O}\right)$, while irreversible dissociation steps would preserve the isotopic identity of the $\mathrm{O}_{2}$ in the reactant mixture, even as chemical conversion increases. Figure 8 shows the oxygen isotopomer distribution as a function of DME conversion in a recirculating batch reactor. No mixed dioxygen isotopomers were detected at any chemical conversion levels $(0-5 \%)$. Thus, dioxygen dissociation steps are irreversible during catalytic DME oxidation on $\mathrm{MoO}_{3} / \mathrm{Al}_{2} \mathrm{O}_{3}$. This conclusion is consistent with the stability of $\mathrm{MoO}_{3}$ against autoreduction in inert or oxygencontaining environments at typical DME oxidation temperatures and with the role and irreversibility of $\mathrm{O}_{2}$ dissociation steps in other oxidation reactions, such as the oxidative dehydrogenation of alkanes on supported $\mathrm{MoO}_{x}, \mathrm{VO}_{x}$, and $\mathrm{WO}_{x}$ domains. ${ }^{29,32,33}$

3.5. Comparison for Methanol and DME Oxidation Kinetics and Catalyst Requirements. DME molecules form two methoxide molecules during each dissociation step, while each $\mathrm{CH}_{3} \mathrm{OH}$ forms only one, yet DME converts to $\mathrm{HCHO}$ more slowly than $\mathrm{CH}_{3} \mathrm{OH}$. Methanol oxidation to $\mathrm{HCHO}$ occurs via quasi-equilibrated dissociation of $\mathrm{O}-\mathrm{H}$ bonds to form adsorbed methoxide followed by kinetically relevant $\mathrm{C}-\mathrm{H}$ bond activation of surface methoxide using lattice oxygen atoms. ${ }^{31}$ First-order $\mathrm{HCHO}$ synthesis turnover rates are about 10 times larger for $\mathrm{CH}_{3} \mathrm{OH}$ than for DME reactants at $493 \mathrm{~K}\left(1.83 \times 10^{-3}\right.$ vs 1.94 $\times 10^{-4} \mathrm{~s}^{-1}$ ), because the $\mathrm{C}-\mathrm{O}$ dissociation steps required to form methoxide precede $\mathrm{C}-\mathrm{H}$ bond activation steps, which limit rates for DME oxidation reactions.
$\mathrm{CH}_{3} \mathrm{OH}$ and DME oxidation rates both depend on the identity of the support used to disperse active oxide domains. , $^{8,9,34-37}$ $\mathrm{CH}_{3} \mathrm{OH}$ oxidation rates on supported polymolybdate monolayers varied by more than a factor of 10 on various supports and rates increased with decreasing electronegativity of support cations $\left(\mathrm{ZrO}_{2} \sim \mathrm{TiO}_{2} \gg \mathrm{Nb}_{2} \mathrm{O}_{5}>\mathrm{Al}_{2} \mathrm{O}_{3}>\mathrm{SiO}_{2}\right) .{ }^{36,37}$ Support effects on supported vanadia catalysts are even stronger, and rates varied by 3 orders of magnitude as a function of support identity. ${ }^{34}$ Rates for DME oxidation and for stoichiometric reduction of $\mathrm{MoO}_{3}$ domains with $\mathrm{H}_{2}$ increased in parallel with changes in the support used to dispersed $\mathrm{MoO}_{3}$ domains $\left(\mathrm{SnO}_{2}>\mathrm{ZrO}_{2}>\mathrm{Al}_{2} \mathrm{O}_{3}>\mathrm{MgO}\right)$, suggesting that the reactivity of active oxide domains depends sensitively on their ability to delocalize electron density during rate-determining steps. ${ }^{9}$ Turnover rates increased with increasing reducibility of Mo centers, which were influenced in turn by the size of the $\mathrm{MoO}_{3}$ domains and by the identity of the support materials. Similar effects were reported earlier for alkane oxidative dehydrogenation, for which kinetically relevant $\mathrm{C}-\mathrm{H}$ bond activation steps required reduction of metal centers during each catalytic turnover. ${ }^{38}$ A similar argument seems plausible for methanol oxidation, which occurs via rate-determining $\mathrm{C}-\mathrm{H}$ bond activation steps, normally associated with the formal reduction of metal centers. Support effects were substantiated when Oyama et al. ${ }^{39}$ showed that the activity of a catalyst correlates with the density of unoccupied electronic states; $\mathrm{MoO}_{x}$ deposited on support materials that readily accept electron density from reducing $\mathrm{C}-\mathrm{H}$ bond cleavage steps in methanol oxidation result in higher conversion rates. ${ }^{39}$

This reasoning becomes less unequivocal for the observed correlations between reducibility and DME oxidation rates, because $\mathrm{H}$-abstraction appears to be kinetically irrelevant and $\mathrm{C}-\mathrm{O}$ bond cleavage, which limits reaction rates, does not require the formal reduction of $\mathrm{Mo}^{6+}$ centers. It appears, however, that electron density at cation sites increases gradually along the reaction sequence, instead of occurring sharply during the formal reduction assumed to occur at the $\mathrm{H}$-abstraction step. The formation of methoxide species, via either $\mathrm{O}-\mathrm{H}$ dissociation in $\mathrm{CH}_{3} \mathrm{OH}$ or $\mathrm{C}-\mathrm{O}$ cleavage in DME, appears to require electron transfer, which is most effectively accommodated by reducible cations. Activated complexes involved in forming methoxide intermediates become stabilized by effective electron delocalization and activation energies consequently decrease. This charge delocalization is imposed by the required cleavage of a bridging metal-oxygen bond, which is replaced by one bond from each metal atom to a methoxide species, a process that leads to charge delocalization of the metal centers due to the different extent of charge separation in $\mathrm{M}-\mathrm{O}-\mathrm{M}$ and $\mathrm{M}-\mathrm{O}-\mathrm{CH}_{3}$.

These arguments find qualitative support in previous studies of methanol reactions, which found that equilibrium constants for $\mathrm{CH}_{3} \mathrm{OH}$ adsorption as methoxides increased 6-fold and rate constants for $\mathrm{H}$-abstraction from methoxide increased $\sim 20$-fold with changes in the support used to dispersed polyvanadate monolayers $\left(\mathrm{CeO}_{2}>\mathrm{ZrO}_{2}>\mathrm{TiO}_{2}>\mathrm{Al}_{2} \mathrm{O}_{3}\right) .{ }^{23}$ These supports have also been reported to influence in a similar sequence the reducibility of $\mathrm{MoO}_{\mathrm{x}}$ and $\mathrm{VO}_{x}$ monolayers, ${ }^{8,9}$ because of their apparent ability to delocalize charge away from the active oxide domains during redox cycles. Similarly, such arguments can rationalize the support effects on our DME oxidation rates over dispersed molybdate domains as DME dissociation is not unlike $\mathrm{CH}_{3} \mathrm{OH}$ dissociation; neither step requires formal reduction of metal centers. 


\section{Conclusions}

In situ infrared spectroscopy at low DME pressures indicated that methoxides are chemisorbed on the $\mathrm{MoO}_{x}$ surface during DME oxidation reactions and that they are intermediates to $\mathrm{HCHO}$ and $\mathrm{CH}_{3} \mathrm{OH}$. Kinetic studies by varying DME and $\mathrm{O}_{2}$ pressures led to $\mathrm{HCHO}$ and $\mathrm{CH}_{3} \mathrm{OH}$ formation rates that were first-order in DME and zero-order in $\mathrm{O}_{2}$ at low DME pressure. These rates approach zero-order in DME and are positive-order in $\mathrm{O}_{2}$ at high DME pressure as lattice oxygen vacancies become abundant. Under these conditions, surface hydroxyl groups formed by methoxide $\mathrm{C}-\mathrm{H}$ activation combine mainly with methoxide to form $\mathrm{CH}_{3} \mathrm{OH}$ (instead of with another hydroxyl group to form water) leading to equimolar $\mathrm{HCHO}$ and $\mathrm{CH}_{3} \mathrm{OH}$ formation. $\mathrm{H}-\mathrm{D}$ kinetic isotope effects indicated that $\mathrm{C}-\mathrm{H}$ bond activation of surface methoxide is not a kinetically relevant step and transient reactions with $\mathrm{CH}_{3}{ }^{16} \mathrm{OCH}_{3}-{ }^{18} \mathrm{O}_{2}$ mixtures demonstrated the kinetic relevance of DME dissociative adsorption at low DME pressure. This step precedes $\mathrm{C}-\mathrm{H}$ bond activation and was found to be nearly irreversible. Reactions with ${ }^{18} \mathrm{O}_{2^{-}}$ ${ }^{16} \mathrm{O}_{2}$ did not produce detectable amounts of ${ }^{16} \mathrm{O}-{ }^{18} \mathrm{O}$; the reoxidation of lattice oxygen vacancies was found to be irreversible.

A reaction mechanism was proposed for DME oxidation and the kinetic rate equations derived from the mechanism were shown to be consistent with spectroscopic studies and with observed dependencies on reactant pressures and with isotopic studies.

Acknowledgment. This study was supported by BP as part of the Methane Conversion Cooperative Research Program at the University of California at Berkeley.

\section{Appendix}

Since $\mathrm{M}-\mathrm{O}$ bonds are broken and formed concurrently, $\mathrm{M}^{*}$ and $\mathrm{O}^{*}$ exist in equal amounts.

$$
\left[\mathrm{M}^{*}\right]=\left[\mathrm{O}^{*}\right]
$$

At low $P_{\text {DME }}$ pressure, the surface is uncovered and oxidized and no methanol is formed. The derivation for $\mathrm{HCHO}$ formation rate is as follows:

$$
\begin{gathered}
\frac{\mathrm{d}\left[* \mathrm{OCH}_{3}\right]}{\mathrm{d} t}=2 K_{1} k_{2} \frac{\left[\mathrm{M}^{*}\right]\left[\mathrm{O}^{*}\right]}{C_{\mathrm{t}}} P_{\mathrm{DME}}-2 k_{3} \frac{\left[* \mathrm{OCH}_{3}\right]\left[\mathrm{O}^{*}\right]}{C_{\mathrm{t}}}=0 \\
{\left[* \mathrm{OCH}_{3}\right]=\frac{K_{1} k_{2}}{k_{3}}\left[\mathrm{M}^{*}\right] P_{\mathrm{DME}}=\frac{K_{1} k_{2}}{k_{3}}\left[\mathrm{O}^{*}\right] P_{\mathrm{DME}}} \\
C_{\mathrm{t}}=\left[\mathrm{M}^{*}\right]+\left[\mathrm{O}^{*}\right]=2\left[\mathrm{O}^{*}\right] \\
{\left[\mathrm{O}^{*}\right]=\frac{C_{\mathrm{t}}}{2}} \\
r_{\mathrm{HCHO}}=k_{3} \frac{\left[* \mathrm{OCH}_{3}\right]\left[\mathrm{O}^{*}\right]}{C_{\mathrm{t}}}=K_{1} k_{2} \frac{\left[\mathrm{M}^{*}\right]\left[\mathrm{O}^{*}\right]}{C_{\mathrm{t}}} P_{\mathrm{DME}} \\
r_{\mathrm{HCHO}}=\frac{1}{4} K_{1} k_{2} P_{\mathrm{DME}}
\end{gathered}
$$

At high $P_{\mathrm{DME}}$ pressure, the rates of $\mathrm{HCHO}$ and $\mathrm{CH}_{3} \mathrm{OH}$ formation are equal. The rate of $\mathrm{HCHO}$ formation can be derived as

$$
\begin{gathered}
\alpha=1=\frac{r_{\mathrm{CH}_{3} \mathrm{OH}}}{r_{\mathrm{HCHO}}}=\frac{k_{4}\left[* \mathrm{OCH}_{3}\right]\left[\mathrm{OH}^{*}\right]}{k_{3}\left[* \mathrm{OCH}_{3}\right]\left[\mathrm{O}^{*}\right]} \\
{[* \mathrm{OH}]=\frac{k_{3}}{k_{4}}[\mathrm{O} *]} \\
\frac{\mathrm{d}[*]}{\mathrm{d} t}=2 k_{3} \frac{\left[* \mathrm{OCH}_{3}\right]=\frac{K_{1} k_{2}}{k_{3}}\left[\mathrm{O}^{*}\right]\left[P_{\mathrm{DME}}\right.}{\mathrm{C}_{\mathrm{t}}}-k_{6} \frac{[*]^{2}}{\mathrm{C}_{\mathrm{t}}} P_{\mathrm{O}_{2}}=0 \\
C_{\mathrm{t}}=\left[\mathrm{M}^{*}\right]+\left[\frac{2 K_{1} k_{2}}{k_{6}} \frac{P_{\mathrm{DME}}}{P_{\mathrm{O}_{2}}}\right)^{1 / 2}\left[\mathrm{O}^{*}\right] \\
{\left[\mathrm{O}^{*}\right]+\left[* \mathrm{OCH}_{3}\right]+\left[* \mathrm{OH}^{*}\right]+[*]} \\
r_{\mathrm{HCHO}}=\frac{C_{\mathrm{t}}}{2+\frac{K_{1} k_{2}}{k_{3}} P_{\mathrm{DME}}+\frac{k_{3}}{k_{4}}+\left(\frac{2 K_{1} k_{2}}{k_{6}} \frac{P_{\mathrm{DME}}}{P_{\mathrm{O}_{2}}}\right)^{1 / 2}} \\
\left\{2+\frac{K_{1} k_{2}}{k_{3}} P_{\mathrm{DME}}+\frac{k_{3}}{k_{4}}+\left(\frac{2 K_{1} k_{2}}{k_{6}} \frac{P_{\mathrm{DME}}}{P_{\mathrm{O}_{2}}}\right)^{1 / 2}\right\}^{2} P_{\mathrm{DME}}
\end{gathered}
$$

At large $P_{\mathrm{DME}} / P_{\mathrm{O}_{2}}$ ratios, lattice oxygen vacancies become the most abundant reactive intermediate. The $\mathrm{HCHO}$ formation rate becomes

$$
\mathrm{r}_{\mathrm{HCHO}}=\frac{1}{2} k_{6} P_{\mathrm{O}_{2}}
$$

\section{References and Notes}

(1) Brown, S. H.; Green, L. A.; Mathias, M. F.; Olson, D. H.; Ware, R. A.; Weber, W. A.; Shinnar, R. U.S. Patent 6,506,954, 2003.

(2) Brown, S. H.; Green, L. A.; Mathias, M. F.; Olson, D. H.; Ware, R. A.; Weber, W. A. U.S. Patent 6,046,372, 2000. 2003.

(3) Brown, S. H.; Shinnar, R.; Weber, W. A. U.S. Patent 6,613,951,

(4) Brown, S. H.; Weber, W. A.; Shinnar, R.; Nariman, K. E.; Green, L. A.; Mathias, M. F.; Olson, D. H.; Ware, R. A. U.S. Patent 6,538,167, 2003.

(5) Barger, P. T. U.S. Patent 5,248,647, 1991.

(6) Fleisch, T. H.; Basu, A.; Gradassi, M. J.; Masin, J. G. Stud. Surf. Sci. Catal. 1997, 107, 117 23.

(7) Li, J. L.; Zhang, X. G.; Inui, T. Appl. Catal., A: Gen. 1996, 147,

(8) Liu, H. C.; Cheung, P.; Iglesia, E. Phys. Chem. Chem. Phys. 2003 , 5,3795

(9) Liu, H. C.; Cheung, P.; Iglesia, E. J. Catal. 2003, 217, 222.

(10) Liu, H. C.; Cheung, P.; Iglesia, E. J. Phys. Chem. B 2003, 107, 4118.

(11) Liu, H. C.; Iglesia, E. J. Catal. 2002, 208, 1.

(12) Lewis, R. M.; Ryan, R. C.; Slaugh, L. H. U.S. Patent 4,442,307, 1984.

(13) Lewis, R. M.; Ryan, R. C.; Slaugh, L. H. U.S. Patent 4,439,624 1984.

(14) Lewis, R. M.; Slaugh, L. H. U.S. Patent 4,435,602, 1984.

(15) Chen, K. D.; Xie, S.; Bell, A. T.; Iglesia, E. J. Catal. 2001, 198, 232.

(16) Iglesia, E.; Baumgartner, J. E.; Price, G. L. J. Catal. 1992, 134 , 549.

(17) Price, G. L.; Iglesia, E. Ind. Eng. Chem. Res. 1989, 28, 839.

(18) Briand, L. E.; Farneth, W. E.; Wachs, I. E. Catal. Today 2000, 62, 219. 6175 .

(19) Burcham, L. J.; Briand, L. E.; Wachs, I. E. Langmuir 2001, 17,

(20) Campbell, S. M.; Jiang, X. Z.; Howe, R. F. Microporous Mesoporous Mater. 1999, 29, 91.

(21) Chung, J. S.; Miranda, R.; Bennett, C. O. J. Chem. Soc. Faraday Trans. 1 1985, 81, 19.

(22) Narishige, N.; Niwa, M. Catal. Lett. 2001, 71, 63.

(23) Burcham, L. J.; Wachs, I. E. Catal. Today 1999, 49, 467. 
(24) Seman, M.; Kondo, J. N.; Domen, K.; Radhakrishnan, R.; Oyama, S. T. J. Phys. Chem. B 2002, 106, 12965.

(25) Groff, R. P. J. Catal. 1984, 86, 215.

(26) Mars, P.; Van Krevelen, D. W. Chem. Eng. Sci. Spec. Suppl. 1954, 3,41 .

(27) Pernicone, N.; Lazzerin, F.; Liberti, G.; Lanzavecchia, G. J. Catal. 1969, 14, 293

(28) Chen, K. D.; Iglesia, E.; Bell, A. T. J. Phys. Chem. B 2001, 105, 646.

(29) Chen, K. D.; Khodakov, A.; Yang, J.; Bell, A. T.; Iglesia, E. J. Catal. 1999, 186, 325.

(30) Argyle, M. D.; Chen, K.; Bell, A. T.; Iglesia, E. J. Phys. Chem. B 2002, 106, 5421.
(31) Machiels, C. J.; Sleight, A. W. J. Catal. 1982, 76, 238.

(32) Chen, K. D.; Bell, A. T.; Iglesia, E. J. Phys. Chem. B 2000, 104, 10059

(33) Chen, K. D.; Iglesia, E.; Bell, A. T. J. Catal. 2000, 192, 197.

(34) Deo, G.; Wachs, I. E. J. Catal. 1994, 146, 323.

(35) Wachs, I. E. In Catalysis; Spivey, J. J., Ed.; The Royal Society of Chemistry: Cambridge, U.K., 1997; Vol. 13; p 37.

(36) Burcham, L. J.; Badlani, M.; Wachs, I. E. J. Catal. 2001, 203, 104.

(37) Hu, H.; Wachs, I. E. J. Phys. Chem. 1995, 99, 10911.

(38) Chen, K. D.; Bell, A. T.; Iglesia, E. J. Catal. 2002, 209, 35.

(39) Oyama, S. T.; Radhakrishnan, R.; Seman, M.; Kondo, J. N.; Domen, K.; Asakura, K. J. Phys. Chem. B 2003, 107, 1845. 